\title{
Tips for Managing Yearly Fishing Income
}

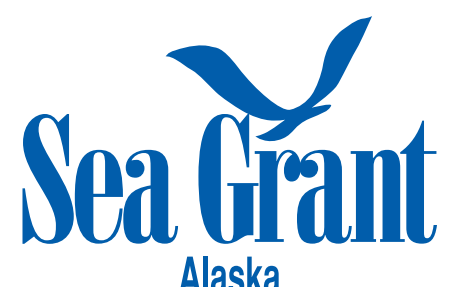

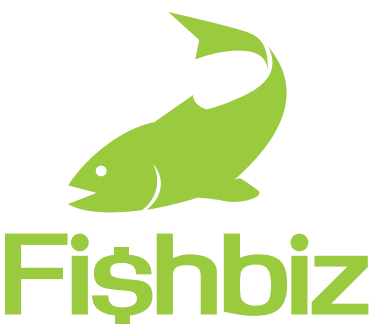

ALASKA FISHERIES BUSINESS ASSISTANCE

\section{by Torie Baker and Glenn Haight}

Whether you fish only during the summer salmon season, or you're longlining off Kodiak all year, managing your profits or losses is an annual drill necessary for longterm business success. Getting tax paperwork together is mandatory, but actual business decisions should be only partly driven by yearly tax demands.

Here are some tips to help organize your financial management to-do list before the end of the year while keeping an eye on long-term business and operation priorities.

\section{Meet Tax Preparer Soon}

With final bills in hand, meet with a tax preparer right away to find out how much tax will be owed. A tax preparer will (1) estimate how much money to set aside for taxes, and (2) want to know about purchases of equipment, gear, and permits to be made before the end of the year. Major investments can be expensed (written off against revenues) and reduce the tax burden, but those expenses must be incurred in the current tax year. So,

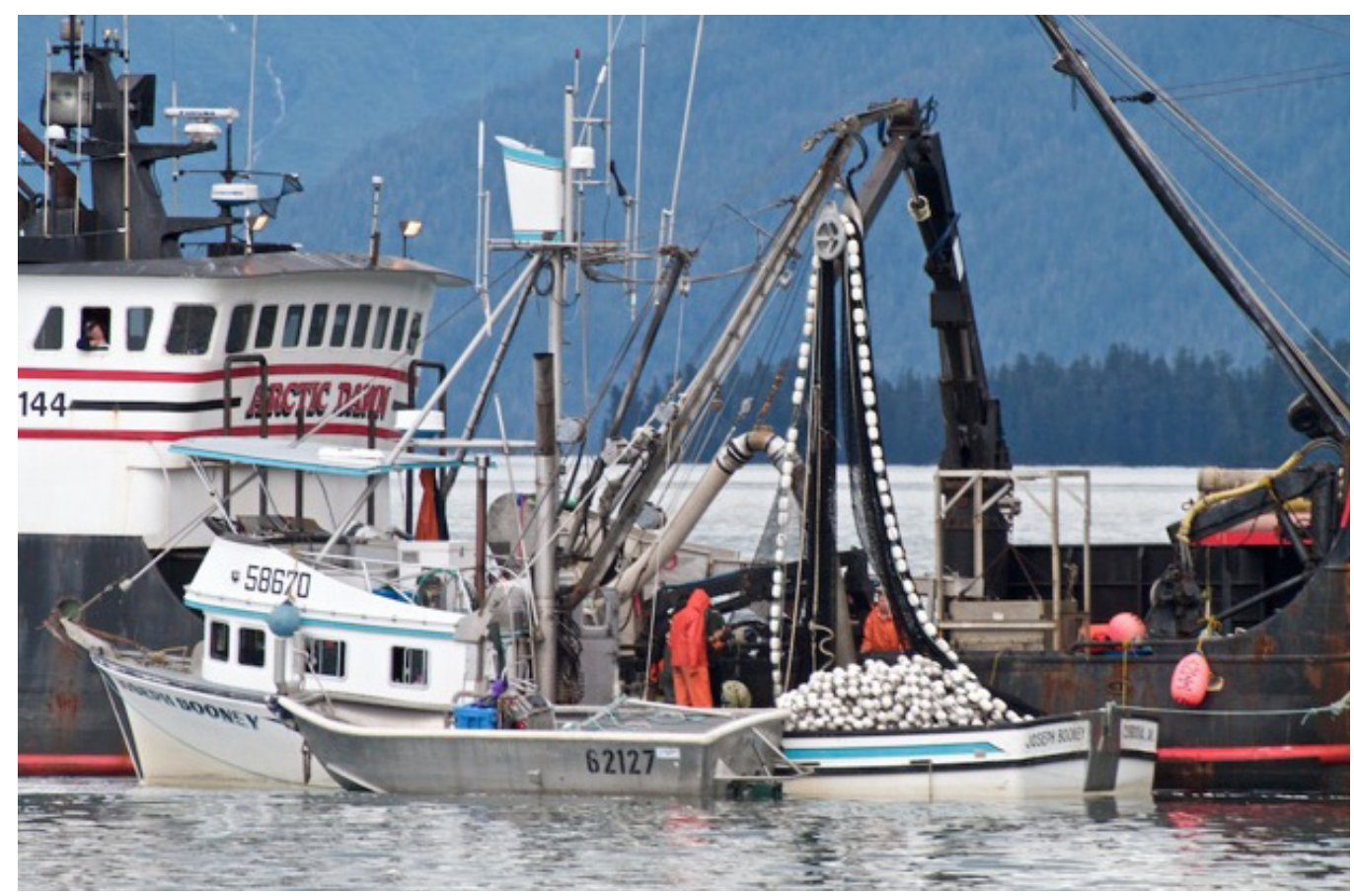

Seiner and tender in Prince William Sound, Alaska. Photo by Dave Partee.
Alaska Sea Grant Marine Advisory Program University of Alaska Fairbanks 1007 W. 3rd Ave., Suite 100 Anchorage, AK 99501 (907) 274-9691

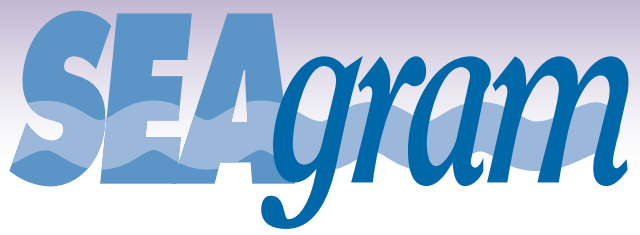

ALASKA SEA GRANT

MARINE ADVISORY PROGRAM

ASG-54 2010

doi:10.4027/tmyfi.2010 
if you have major work to do on a vessel or gear, consider lining up boatyard time, gear hanging, or engine or refrigeration purchases before the end of the year. Also, ask your tax preparer about changes to the current tax laws.

\section{Strategize Long-Term Reinvestment in Your Operation}

It's important to set aside money at the end of the season for eventual engine/ machinery or whole boat replacement. Too often, operators taking the tax deduction for depreciation are not also setting aside the money to actually replace depreciated or worn out assets. If an engine typically lasts 5,000 hours and replacement costs are $\$ 40,000$, the operator may consider putting at least $\$ 8$ into an engine account for every tachometer hour. It might be even better to save $\$ 20$ for each hour to cover the entire vessel depreciation. Remember, it's not zincs and belts that require big cash outlays-it's engines, fuel tanks, etc.

\section{Pay Down Your Debts}

Did lean fishing years push you to the limit on your debt? Are you current on permit and vessel payments? Explore with your lender whether making bigger rather than minimal payments will put your business in a better long-term financial position. Before deciding to pay down loans in advance, carefully consider your year-end tax liability and next season start-up cash needs.

\section{Think About Refinancing Debts}

At the time of this publication, loan rates are very low for qualified borrowers. If you are paying a high interest rate on any loan, now is a good time to consider refinancing. For instance, lowering interest on an 8 year loan of $\$ 50,000$ from $9 \%$ to $7 \%$ can save $\$ 5,000$ (minus closing costs).

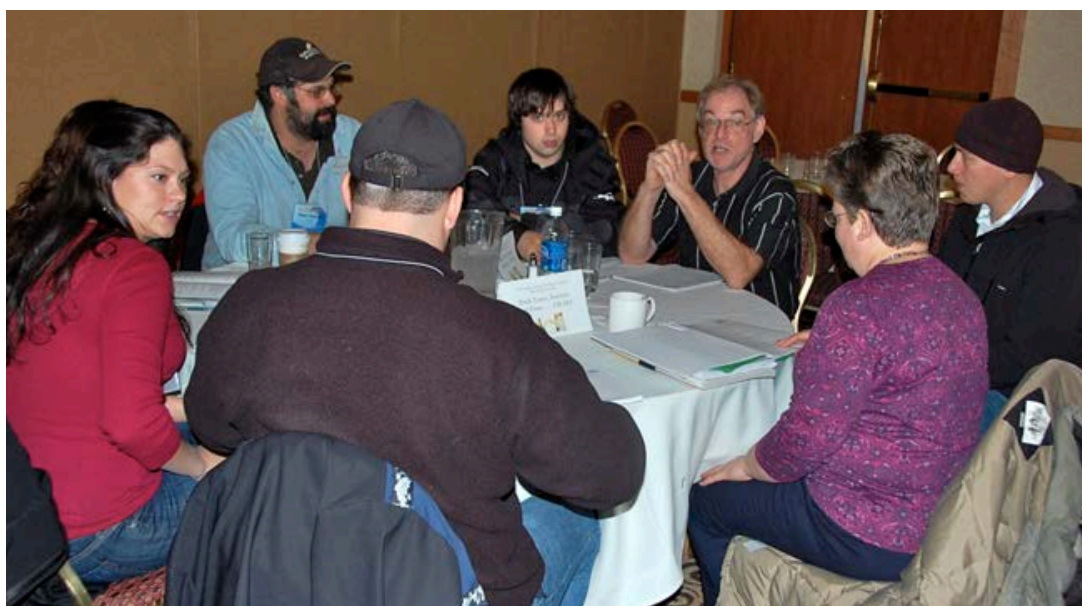

Reduce credit card debt wherever possible. Considering that a $\$ 50,000$ loan for 8 years at $24 \%$ will cost $\$ 47,000$ more than a $7 \%$ loan, the refinanced "return" can be much better than on many other investments.

\section{Retirement Savings}

Is retirement something just gray-haired skippers talk about over coffee? Remember, retirement will happen and you need to be in charge of your retirement income picture long before you tie up the boat for the last time. Always consider putting maximum annual contributions into a traditional IRA or a SEP

Alaska Young Fishermen Summit participants discuss importance of tax planning and finances with Bristol Bay fisherman and tax preparer Jerry Liboff. Photo by Kristi McGinnis. (simplified employee pension)_some years it might make more sense than others. For those skippers with the coffee cups, remember the IRS allows for bigger contributions into qualified retirement accounts for folks age 50 and older. If you're younger, time is on your side. Investing even small amounts early on can pay off over the long haul. For example, investing $\$ 200$ monthly, earning 6\% interest, will be worth over $\$ 200,000$ in 30 years.

\section{Saving for Next Year's Start-up}

Over the winter, review fixed costs like insurance, moorage, and storage to see if consolidating, changing providers, or sharing services with a fishing partner can reduce expenses. Remember, insurance is an important cost of doing business, so reducing 


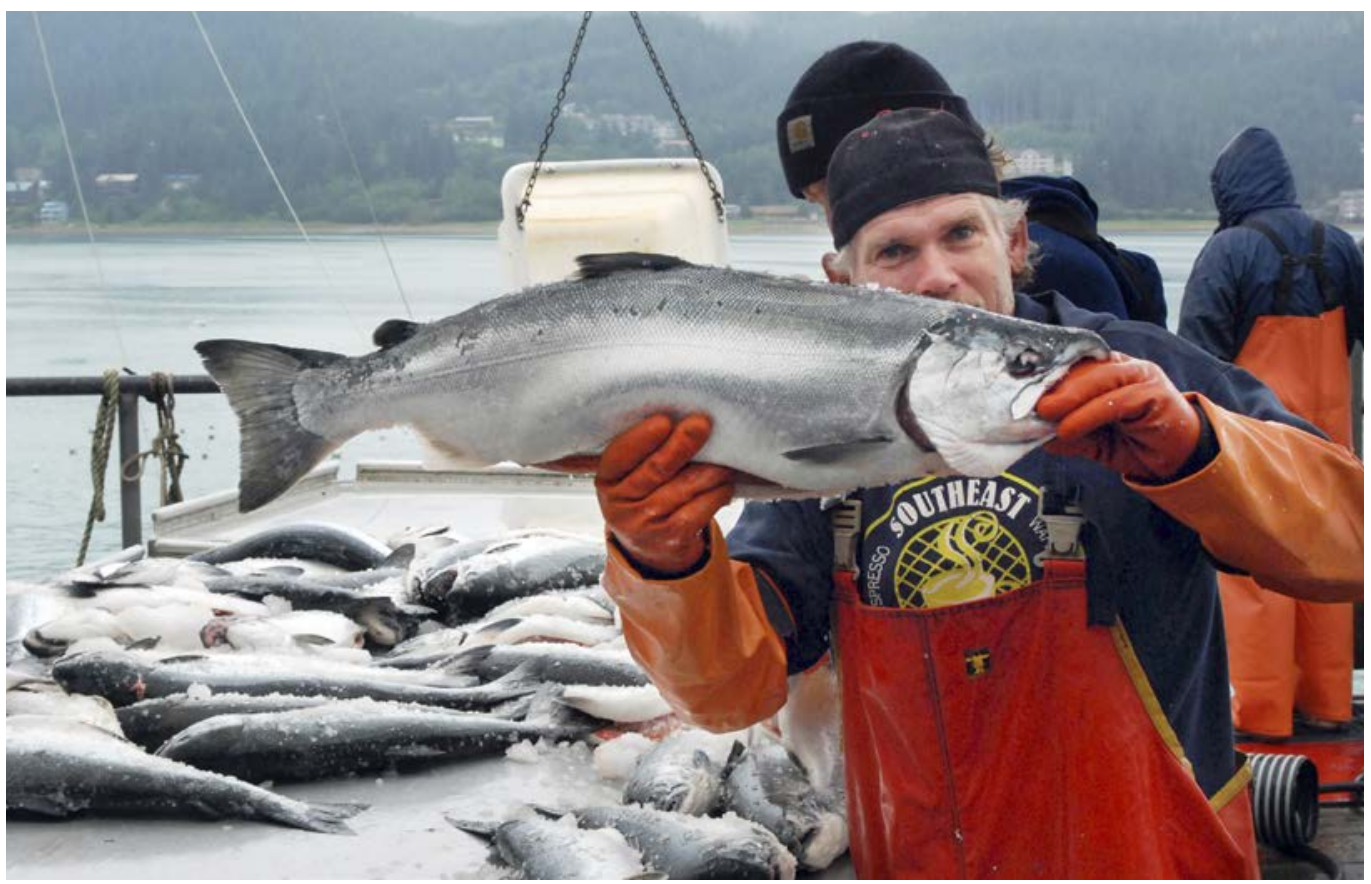

A seafood processing plant worker in Juneau shows off a freshly caught coho (silver) salmon.

Photo by Kurt Byers.

coverage to reduce premium costs is a serious consideration to be thoroughly reviewed. If you are using a bank, processor, or family member for spring start-up money and paying interest on grubstakes, earmark earnings this year to self-finance as much of next season's start-up or maintenance costs as is reasonable.

Here are other areas to annually consider in your financial planning:

\section{Buying into an Operation}

If in the future you're considering buying your own fishing operation, remember that watching permit, quota, and vessel prices is only one aspect of getting into the business of fishing. Build good business habits even before applying for a loan, such as strengthening your credit scores by making debt payments on time, settling on (and sticking to) a budget, and prioritizing short-term and long-term business expenditures. Remember, lenders want at least $20 \%$ down as well as collateral to secure a loan. For example, if that boat and permit cost $\$ 150,000$, you need at least $\$ 30,000$.

\section{Succession Planning}

If you are nearing retirement, remember that wise business succession planning is complex, and completely transferring your operation to new owners may take three to five years to accomplish. Make sure liens are cleared, the vessel has a strong maintenance record, and deferred maintenance is caught up. If a retirement goal is to keep the business in your local community, start working with an individual (crew, son, daughter) who wants to succeed you in running the operation.

\section{A Final Note}

Just as important as hiring good crew, find a tax preparer or financial planner familiar with fishing business operations to help you. Ask around and get referrals from your lender, family, or fellow fishermen. The Alaska Business Development Center (www.abdc.org/services.html) is a nonprofit organization that partners with others to 


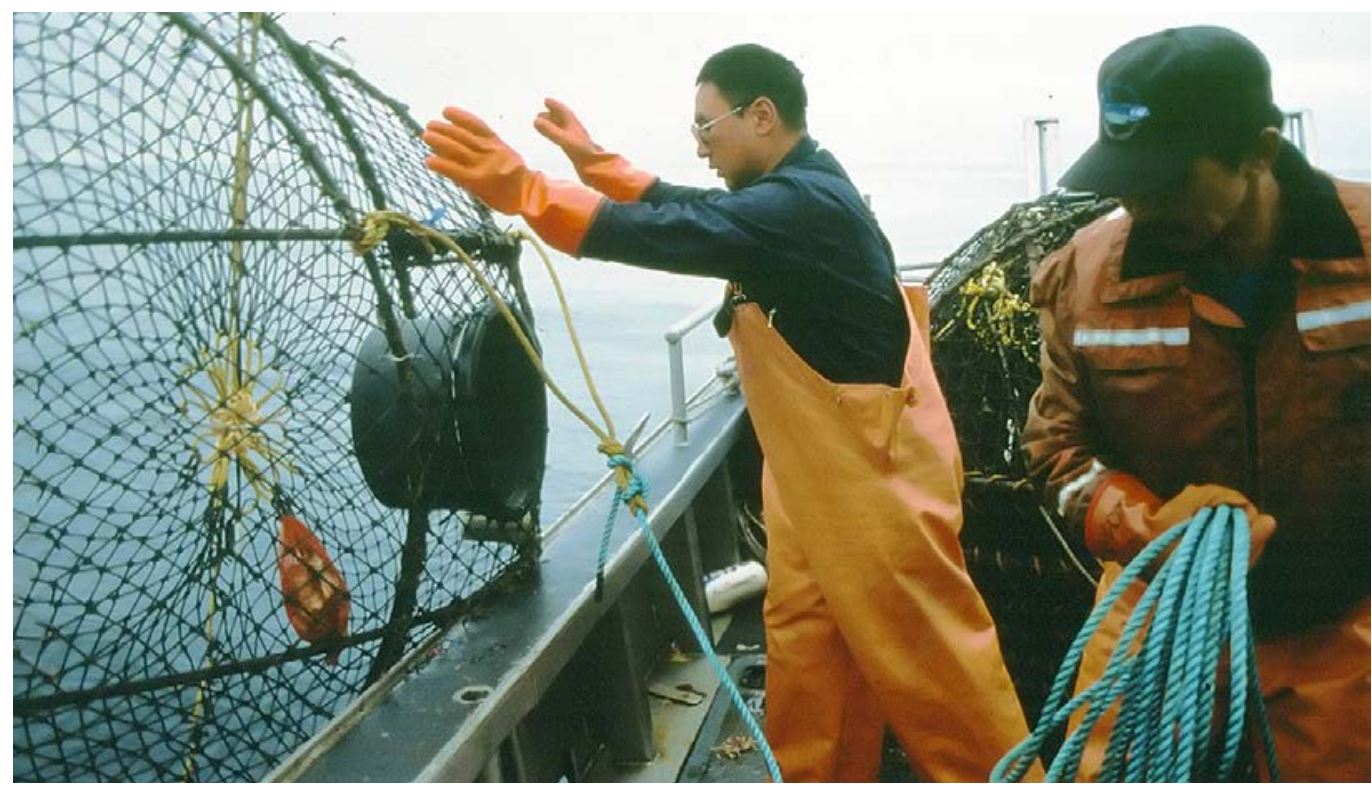

Crab fishermen in Norton Sound. Photo by Deborah Mercy.

provide tax preparation and small business consultation for commercial fishermen throughout Alaska. Many Native corporations and Community Development Quota (CDQ) organizations also assist with fishing business planning.

For online business planning tools, sample crew contracts, etc., visit the Marine Advisory Program's Fishbiz website at marineadvisory.org/fishbiz.

Remember, your business success is more than adding up fish tickets at the end of a season. Whether captain or crew, the season is not done until bills are settled, the boat is winterized, taxes are estimated, and business, family, and personal financial needs (including your retirement income) are evaluated.

\section{Torie Baker}

Marine Advisory Agent Alaska Sea Grant Marine Advisory Program University of Alaska Fairbanks P.O. Box 830

Cordova, AK 99574

(907) 424-3673

torie@sfos.uaf.edu

\section{Glenn Haight}

Fisheries Business Specialist Alaska Sea Grant Marine Advisory Program University of Alaska Fairbanks 1108 F. St., Suite 215

Juneau, AK 99801 (907) 796-6046 glenn.haight@alaska.edu

\section{Torie Baker is the Alaska Sea Grant Marine Advisory Program (MAP) agent in Cordova and Glenn Haight is MAP's fisheries business specialist in Juneau. MAP is a University of Alaska Fairbanks extension program providing information and resources for marine-related Alaska businesses.}

The Alaska Sea Grant College Program is a marine research, education, and extension service headquartered at the University of Alaska Fairbanks School of Fisheries and Ocean Sciences.

Alaska Sea Grant is supported by the National Oceanic and Atmospheric Administration Office of Sea Grant, Department of Commerce, under grant no. NA06OAR4170097 (projects A/161-02 and A/151-01), and by the University of Alaska with funds appropriated by the state.

For information on undergraduate and graduate opportunities in marine biology, fisheries, oceanography, and other marine-related fields at the University of Alaska Fairbanks School of Fisheries and Ocean Sciences, visit http://www.sfos.uaf.edu/.

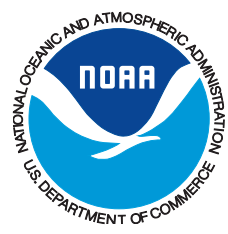

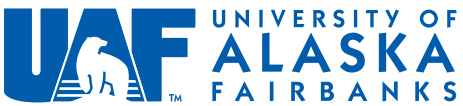
School of Fisheries and Ocean Sciences America's Arctic University
Marine Advisory Program University of Alaska Fairbanks 1007 West 3rd Ave., Suite 100 Anchorage, AK 99501 (907) 274-9691 map@sfos.uaf.edu marineadvisory.org

\author{
Alaska Sea Grant \\ University of Alaska Fairbanks \\ PO Box 755040 \\ Fairbanks, AK 99775 \\ (888) 789-0090 \\ fypubs@uaf.edu \\ alaskaseagrant.org
}

